\title{
Plasma endothelin-1 levels in patients with systemic sclerosis: influence of pulmonary or systemic arterial hypertension
}

Sergio Morelli, Claudio Ferri, Letizia Di Francesco, Roberta Baldoncini, Marta Carlesimo, Ugo Bottoni, Giuliana Properzi, Anna Santucci, Guido Valesini

\begin{abstract}
Objectives-To investigate the behaviour of circulating endothelin-1 (ET-1) in patients affected by systemic sclerosis and to elucidate the relationship between systemic and pulmonary plasma peptide and arterial pressure levels.
\end{abstract}

Methods-Plasma ET-1 concentrations were determined in $\mathbf{4 8}$ patients affected by systemic sclerosis (41 women, seven men; mean age 47.2 (SD 5.5) years) with or without systemic or pulmonary hypertension (or both). A group of 18 normal volunteers served as controls (15 women, three men; mean age $45 \cdot 0(10 \cdot 1)$ years).

Results-Plasma ET-1 levels were significantly greater in patients affected by systemic sclerosis $(1.65(0.29) \mathrm{pg} / \mathrm{ml})$ than in controls $(0.63(0 \cdot 19) \mathrm{pg} / \mathrm{ml})(\mathrm{p}<0.0001)$. Pulmonary artery systolic hypertension alone was present in 14 patients with systemic sclerosis $(50.5$ (8.49) $\mathrm{mm} \mathrm{Hg}$, range $37-67 \mathrm{~mm} \mathrm{Hg}$ ), and systemic hypertension alone (160.7 (5.9)/100.6 (3.2) $\mathrm{mm} \mathrm{Hg}$ ) was present in 11 patients. Both conditions were present in 12 patients, while 11 patients had systemic sclerosis without pulmonary or systemic hypertension. There were no significant differences in plasma ET-1 levels between patients with pulmonary hypertension alone $(1.62(0.21) \mathrm{pg} / \mathrm{ml})$ and those with systemic hypertension alone $(1.65(0.43) \mathrm{pg} / \mathrm{ml})$. In particular, patients with normal pulmonary artery and systemic pressures $(n=11)$ had plasma ET-1 concentrations identical to those found in patients $(n=12)$ with both pulmonary and systemic hypertension (1.70 (0.15) v $1.64(0.35) \mathrm{pg} / \mathrm{ml}$, respectively). No correlations were observed between plasma ET-1 and either pulmonary or systemic pressures.

Conclusion-Systemic sclerosis is characterised by increased plasma ET-1 levels, but neither pulmonary nor systemic hypertension are accompanied by further increase in plasma peptide levels.

(Ann Rheum Dis 1995; 54: 730-734)

Systemic sclerosis (SSc) is known to be characterised by functional disorders of the regulation of microvascular blood flow, increased vascular resistance, and progressive perivascular fibrosis of the skin and visceral organs. ${ }^{1}$ The lungs are often clinically involved, ${ }^{2}$ and pulmonary hypertension is a frequent cause of death. ${ }^{4}$ Systemic hypertension is also common, both in the presence and in the absence of SSc-related kidney damage. $^{5}$

Increased plasma concentrations of the most potent endothelium derived vasoconstrictor, endothelin-1 (ET-1), has been demonstrated in patients with SSc. ${ }^{67}$ In view of the biological actions of ET-1, this finding has been interpreted as a possible pathogenic mechanism in SSc, rather than a simple consequence of microvascular damage. ${ }^{7}$ In particular, it has been suggested that ET-1 may favour the initiation of vascular and perivascular fibrosis in the pulmonary and systemic vascular beds, thus leading to a progressive increase in blood pressure in both.

Although possible confirmation of this intriguing hypothesis has recently come from the in vitro demonstration of a profibrotic action of ET-1 in human perivascular fibroblasts, ${ }^{7}$ little is known of the influence of pulmonary or systemic hypertension on circulating ET-1 concentrations in patients affected by SSc.

We have investigated this by measuring plasma ET-1 levels in these patients and evaluating the relationship between changes in peptide concentrations and both pulmonary and systemic arterial pressures.

\section{Patients and methods}

Forty eight patients (41 women, seven men; mean age 47.2 (SD 5.5) years) were randomly selected from presenting outpatients, solely on the basis of a definite diagnosis of SSc that met with American Rheumatism Association (ARA) criteria, ${ }^{8}$ willingness to participate, and absence of both diabetes mellitus and renal failure. In particular, serum creatinine was $<115 \mu \mathrm{mol} / \mathrm{l}$ and creatinine clearance was $>1.5 \mathrm{ml} / \mathrm{s}$ in all patients. All patients were white, non-smokers $(n=37)$ or ex-smokers $(n=11)$, and had no concomitant diseases. Patients were treated with D-penicillamine $(n=11)$, calcium antagonists $(n=15)$, ketanserin $(n=9)$, captopril $(n=14)$, and prazosin $(n=8)$. Nine patients were taking combined treatment (D-penicillamine and calcium antagonists, or calcium antagonists and captopril). All treatments were interrupted one week before the study. 
To obtain the normal range of plasma ET-1 levels, a group of 18 healthy volunteers (15 women, three men; mean age 45.0 (10.1) years) was used as control.

\section{LABORATORY STUDIES}

After informed consent, at 09:00, an antecubital vein of the non-dominant forearm was cannulated with the patient lying comfortably in the supine position in an air conditioned room. To avoid the ET-1 release that usually follows venous cannulation and blood stasis, ${ }^{9}$ blood sampling was made one hour after placement of the intravenous line. Each plasma sample $(1 \mathrm{ml})$ was injected onto $\mathrm{C}_{18}$ octyloecylsilane columns (Amersham, Amersham, UK) previously activated with $0 \cdot 1 \%$ trifluoroacetic acid. The eluate was analysed by reverse phase high pressure liquid chromatography over 70 minutes, using a linear gradient of $15-75 \%$ acetonitrile/ $0 \cdot 1 \%$ trifluoroacetic acid in water. Fractions were collected every minute and dried under vacuum by a centrifugal evaporator system (Gyrovap, Howe and Co, London, UK) before reconstitution in $1 \mathrm{ml}$ of buffer $(50 \mathrm{mmol} / \mathrm{h}$ phosphate buffer, $\mathrm{pH} 7 \cdot 4$, containing $0.9 \%$ sodium chloride, $0.05 \%$ sodium azide and $0.5 \%$ bovine serum albumin). The chromatography resulted in a single peak of immunoreactive ET, corresponding exactly with the position of elution of human ET-1 standard and ${ }^{125} \mathrm{I}-\mathrm{ET}-1$. ET-1 immunoreactivity was then assayed on reconstituted samples using a sensitive radioimmunoassay (Peninsula Laboratories, Belmont, CA). Human ET-1 (Peptide Institute, Osaka, Japan) was used as standard. Interassay and intra-assay variations were $<10 \%$. Mean recovery of human ET-1 standard using our method was $85 \%$. Cross reactivity of ET-1 antibody with ET-2 and ET-3 was $<7 \%$, according to the supplier.

Other routine laboratory tests were carried out in our laboratories by standard methods.

\section{ECHOCARDIOGRAPHY}

Echocardiographic studies were performed using commercially available equipment, using left parasternal and apical approaches. A complete $M$ mode and two dimensional evaluation was performed in both patients and controls. Functioning of all cardiac valves was also investigated by colour Doppler. Conventionally, flows directed toward the transducer were codified in red and flows directed away from the transducer were coded blue. Green colour (variance) was added to represent flow turbulence. Great care was taken in detecting tricuspid regurgitation: the transducer was manipualted to obtain the best visualisation of valvular insufficiency by colour-flow Doppler mapping and a continuous wave Doppler cursor was positioned parallel to flow. If the angle of intersection between Doppler cursor and tricuspid regurgitant flow was $>20^{\circ}$, attempts to detect tricuspid insufficiency were repeated from a subcostal transducer position. In some cases, the subject was asked to take a deep breath and to remain in inspiratory apnoea: in this way, it was usually possible to obtain an optimal representation of tricuspid regurgitant flow and to place the Doppler cursor in parallel with it. The same manoeuvres were then repeated using the non-imaging, high sensitivity Pedoff transducer guided by audio and visual signals. In our experience, the latter transducer permits the detection of better defined Doppler envelopes and higher velocities than combined imaging and continuous wave Doppler probe. The maximum velocity of the signal tracing observed on at least two consecutive cardiac cycles was used for calculation of the pressure gradient. Optimal signals were assumed to be oriented parallel to the direction of regurgitation and thus a flow angle correction for velocity was not used. The transtricuspid systolic pressure gradient (TSPG) (in $\mathrm{mm} \mathrm{Hg}$ ) was calculated on the basis of the modified Bernoulli equation: ${ }^{10}$ TSPG $=4 V^{2}$, where $V$ represents the peak systolic velocity of the right ventricle to right atrium signal. To calculate pulmonary artery systolic pressure, $10 \mathrm{~mm} \mathrm{Hg}$ (estimated systolic right atrial pressure) was added to the value for TSPG. ${ }^{11}$ Pulmonary systolic hypertension was defined as $>35 \mathrm{~mm} \mathrm{Hg}$.

\section{BLOOD PRESSURE MEASUREMENTS}

Blood pressures were evaluated on at least three different occasions by our medical staff, on each occasion, 15 minutes after the patient assumed the supine position, in an air conditioned room $\left(21-23^{\circ} \mathrm{C}\right)$. A standard Riva-Rocci manometer with a cuff of appropriate size and a stethoscope located over the brachial artery were used. Blood pressure was measured four times at three minute intervals. The first measurement was discarded and the mean of the last three pressures calculated. Systemic hypertension was defined as systolic pressure $>160 \mathrm{~mm} \mathrm{Hg}$, diastolic pressure $>95 \mathrm{~mm} \mathrm{Hg}$, or both, on at least three consecutive occasions.

\section{STATISTICAL ANALYSIS}

Unless otherwise stated, data are reported as mean (SD). Differences between groups were calculated by analysis of variance and Fisher's exact test, as appropriate. Logistic regression analysis was performed to evaluate the influence of various SSc features (age, gender, body weight, systolic blood pressure, pulmonary artery systolic pressure, disease subgroup, etc) on ET-1 levels. Correlations between linear variables were evaluated by linear regression analysis. Statistical significance was established at $\mathrm{p}<0.05$.

\section{Results}

Forty patients of our study population had the diffuse form of SSc, while eight had the limited form, as defined by location and extent of skin involvement. ${ }^{12}$ Disease duration (evaluated from the first appearance of Raynaud's 
Table 1 General characteristics of the study population

\begin{tabular}{lcc}
\hline & $\begin{array}{c}\text { Patients with SS } \\
(n=48)\end{array}$ & $\begin{array}{c}\text { Control subjects } \\
(n=18)\end{array}$ \\
\hline Gender $(\mathrm{F} / \mathrm{M})$ & $41 / 7$ & $15 / 3$ \\
Age (years) & $47 \cdot 2(5 \cdot 5)$ & $45 \cdot 0(10 \cdot 1)$ \\
Systolic blood pressure $(\mathrm{mm} \mathrm{Hg})$ & $144 \cdot 8(4 \cdot 1)$ & $125 \cdot 3(3 \cdot 5)^{\star \star \star}$ \\
Diastolic blood pressure $(\mathrm{mm} \mathrm{Hg})$ & $95 \cdot 5(2 \cdot 7)$ & $82 \cdot 5(3 \cdot 5)^{\star \star \star}$ \\
Heart rate (beats/min) & $74 \cdot 6(3 \cdot 5)$ & $76 \cdot 4(2 \cdot 6)$ \\
Body mass index $\left(\mathrm{kg} / \mathrm{m}^{2}\right)$ & $21 \cdot 4(1 \cdot 4)$ & $23 \cdot 6(1 \cdot 3)^{\star}$ \\
Serum creatinine $(\mu \mathrm{mol} / \mathrm{l})$ & $96 \cdot 8(3 \cdot 8)$ & $89 \cdot 7(3 \cdot 2)$ \\
Creatinine clearance $(\mathrm{ml} / \mathrm{s})$ & $1 \cdot 61(0 \cdot 07)$ & $1 \cdot 72(0 \cdot 09)$ \\
Fasting blood glucose $(\mathrm{mmol} / \mathrm{m})$ & $5 \cdot 2(1 \cdot 4)$ & $5 \cdot 1(0 \cdot 1)$ \\
Total cholesterol $(\mathrm{mmol} / \mathrm{m})$ & $4 \cdot 4(0 \cdot 9)$ & $4 \cdot 8(0 \cdot 2)$ \\
Triglycerides $(\mathrm{mmol} / \mathrm{l})$ & $1 \cdot 1(0 \cdot 1)$ & $1 \cdot 3(0 \cdot 1)$ \\
\hline
\end{tabular}

Values are mean (SD)

${ }^{\star} p<0.05 ;{ }^{\star \star \star} p<0.0001$ $(p=0.001)$. Pulmonary hypertension, either alone or in combination with systemic arterial hypertension, was present in 26 SSc patients $(54 \%)$ (pulmonary systolic pressure 48.6 $(7 \cdot 85) \mathrm{mm} \mathrm{Hg}$, range $36-67 \mathrm{~mm} \mathrm{Hg}$ ), but in none of the control subjects $(p<0.0001)$. Plasma ET-1 levels were not influenced by the presence of pulmonary hypertension, being $1.63(0.28) \mathrm{pg} / \mathrm{ml}$ in patients with, and 1.68 $(0.31) \mathrm{pg} / \mathrm{ml}$ in patients without this condition $(n=22)$ (NS).

Mean systemic arterial pressure in patients affected by SSc was $144 \cdot 8(4 \cdot 1) /$ $95.5(2 \cdot 7) \mathrm{mm} \mathrm{Hg}$, being normal (128.1 (2.5)/ $85.5(2 \cdot 1) \mathrm{mm} \mathrm{Hg})$ in 25 patients $(52 \%)$, and increased $(161.5(11.8) / 105.6(3.4) \mathrm{mm} \mathrm{Hg})$ in 23 ( $\mathrm{p}<0.0001$ for hypertensives $v$ normotensives) of whom 12 also had pulmonary hypertension. Plasma ET-1 levels were similar in both groups $(1.65(0.18) \mathrm{pg} / \mathrm{ml}$ and 1.65 $(0.38) \mathrm{pg} / \mathrm{ml}$, respectively, NS). All control subjects had normal blood pressures (125.5 (3.5)/82.5 (3.5) mm Hg) $(\mathrm{p}<0.0001 v$ all patients with SSc).

We were able to identify four subgroups in our study population (table 2): 11 patients with neither pulmonary nor systemic hypertension, 14 with pulmonary hypertension alone, 11 with systemic hypertension alone, and 12 with both these conditions. Plasma ET-1 levels were substantially similar in each subgroup (fig 2).

The presence of diffuse rather than the limited form of SSc did not influence plasma ET-1 levels: circulating peptide concentrations were $1.62(0.39) \mathrm{pg} / \mathrm{ml}$ in patients with diffuse SSc $(n=40)$ and $1.68(0.14) \mathrm{pg} / \mathrm{ml}$ in those with limited SSc $(n=8)(p=0.904 ;$ NS).

Plasma ET-1 levels were not correlated with pulmonary artery systolic pressure (fig 3), or with systemic systolic, diastolic, and mean blood pressures. Logistic regression analysis showed no influence of haemodynamic parameters and clinical features on ET-1 levels.

\section{Discussion}

This study has confirmed previous reports on the presence of increased ET-1 concentrations in patients with SSc. ${ }^{6713}$ In contrast, we were not able to confirm the existence of a correlation between plasma peptide concentrations and either pulmonary artery systolic

Figure 1 Circulating endothelin-1 (ET-1) concentrations in patients with systemic sclerosis $(\square)(n=48)$ and control subjects $(\square)(n=18)$. T bars represent mean values (SD). Significant difference between two mean values $(p<0.0001)$.

Table 2 General characteristics of each subgroup of patients with systemic sclerosis

\begin{tabular}{|c|c|c|c|c|c|}
\hline & \multicolumn{5}{|l|}{ Patient group } \\
\hline & $\begin{array}{l}P H \\
(n=14)\end{array}$ & $\begin{array}{l}S H \\
(n=11)\end{array}$ & $\begin{array}{l}P H+S H \\
(n=12)\end{array}$ & $\begin{array}{l}S S \\
(n=11)\end{array}$ & $\begin{array}{l}C \\
(n=18)\end{array}$ \\
\hline $\begin{array}{l}\text { Gender }(\mathrm{F} / \mathrm{M}) \\
\text { Age (years) } \\
\text { Systolic blood pressure }(\mathrm{mm} \mathrm{Hg}) \\
\text { Diastolic blood pressure }(\mathrm{mm} \mathrm{Hg}) \\
\text { Heart rate (beats/min) } \\
\text { Body mass index }\left(\mathrm{kg} / \mathrm{m}^{2}\right) \\
\text { Serum creatinine }(\mu \mathrm{mol} / /) \\
\text { Creatinine clearance }(\mathrm{ml} / \mathrm{s}) \\
\text { Fasting blood glucose }(\mathrm{mmol} / \mathrm{l}) \\
\text { Total cholesterol }(\mathrm{mmol} / \mathrm{l}) \\
\text { Triglycerides }(\mathrm{mmol} / \mathrm{n})\end{array}$ & $\begin{array}{l}13 / 1 \\
45 \cdot 1(8 \cdot 7) \\
126 \cdot 0(1 \cdot 4) \\
83 \cdot 6(2 \cdot 0) \\
76 \cdot 5(5 \cdot 3) \\
21 \cdot 1(1 \cdot 1) \\
95 \cdot 5(6 \cdot 8) \\
1 \cdot 63(0 \cdot 15) \\
5 \cdot 0(0 \cdot 6) \\
4 \cdot 3(0 \cdot 2) \\
1 \cdot 0(0 \cdot 2)\end{array}$ & $\begin{array}{l}9 / 2 \\
49 \cdot 2(2 \cdot 7) \\
160 \cdot 7(5 \cdot 9) \\
100 \cdot 6(3 \cdot 2) \\
72 \cdot 3(2 \cdot 1) \\
21 \cdot 6(1 \cdot 3) \\
99 \cdot 7(3 \cdot 2) \\
1 \cdot 65(0 \cdot 09) \\
5 \cdot 1(0 \cdot 1) \\
4 \cdot 8(0 \cdot 2) \\
1 \cdot 3(0 \cdot 1)\end{array}$ & $\begin{array}{l}10 / 2 \\
46 \cdot 0(10 \cdot 1) \\
162 \cdot 3(5 \cdot 8) \\
110 \cdot 7(3 \cdot 7) \\
74 \cdot 4(2 \cdot 6) \\
20 \cdot 9(2 \cdot 2) \\
98 \cdot 3(2 \cdot 1) \\
1.59(0 \cdot 02) \\
4 \cdot 8(2 \cdot 1) \\
4 \cdot 2(1 \cdot 3) \\
1 \cdot 0(0 \cdot 2)\end{array}$ & $\begin{array}{l}10 / 1 \\
48 \cdot 5(0 \cdot 5) \\
130 \cdot 2(3 \cdot 6) \\
87 \cdot 4(2 \cdot 2) \\
75 \cdot 2(4 \cdot 1) \\
22 \cdot 3(1 \cdot 0) \\
93 \cdot 8(3 \cdot 1) \\
1 \cdot 58(0 \cdot 05) \\
4 \cdot 8(3 \cdot 0) \\
4 \cdot 6(2 \cdot 0) \\
1 \cdot 1(0 \cdot 2)\end{array}$ & $\begin{array}{l}15 / 3 \\
45 \cdot 0(10 \cdot 1) \\
125 \cdot 5(3 \cdot 5) \\
82 \cdot 5(3 \cdot 5) \\
76 \cdot 4(2 \cdot 6) \\
23 \cdot 6(1 \cdot 3) \\
89 \cdot 7(3 \cdot 2) \\
1 \cdot 72(0 \cdot 09) \\
5 \cdot 1(0 \cdot 1) \\
4 \cdot 8(0 \cdot 2) \\
1 \cdot 3(0 \cdot 1)\end{array}$ \\
\hline
\end{tabular}

Values are mean (SD). $\mathrm{PH}=$ Pulmonary hypertension; $\mathrm{SH}=$ systemic
or systemic hypertension; $\mathrm{C}=$ control subjects. 


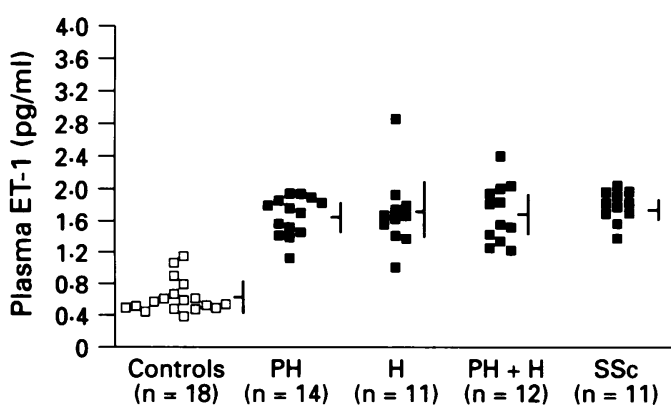

Figure 2 Plasma endothelin-1 (ET-1) concentrations in patients affected by systemic sclerosis (SS) ( $\square)(n=48)$ and in age- and sex-matched control subjects ( $\square$ ) $(n=18) . P H=S S$ with pulmonary artery systolic hypertension; $H=S S$ with systemic arterial hypertension; $P H+H=S S$ with both pulmonary artery systolic hypertension and systemic arterial hypertension; $S S=S S$ with normal pulmonary artery and systemic arterial pressure levels. T bars represent mean values (SD). All patient groups mean values significantly different from controls $(p<0.0001)$.

pressure $^{14-17}$ or systemic systolic, diastolic, and mean arterial pressures. ${ }^{18-20}$ Furthermore, our findings disagree with previous reports ${ }^{14-16}$ describing the presence of increased plasma ET-1 in patients affected by primary or secondary pulmonary hypertension.

One possible explanation for this discrepancy may be the small size of our study population. ${ }^{21}$ However, another recent report in patients with SSc with either echo-Doppler or invasive evidence of pulmonary hypertension also failed to demonstrate increased circulating ET-1 in comparison with patients with SSc and normal pulmonary pressures. ${ }^{22}$ Nevertheless, in that study, ${ }^{22}$ the prevalence of pulmonary hypertension was low (20\%) compared with expected values (ranging from $33 \%$ with invasive to $48 \%$ with non-invasive methods). ${ }^{23}{ }^{24}$ We used the Doppler echocardiographic method ${ }^{11}$ for the assessment of pulmonary artery systolic pressure, and it may be argued that this technique may be insufficiently accurate for this purpose. However, simultaneous determinations of pulmonary artery systolic pressure by right heart catetherisation and continuous wave Doppler demonstrated a close correspondence between the two methods. ${ }^{11}$

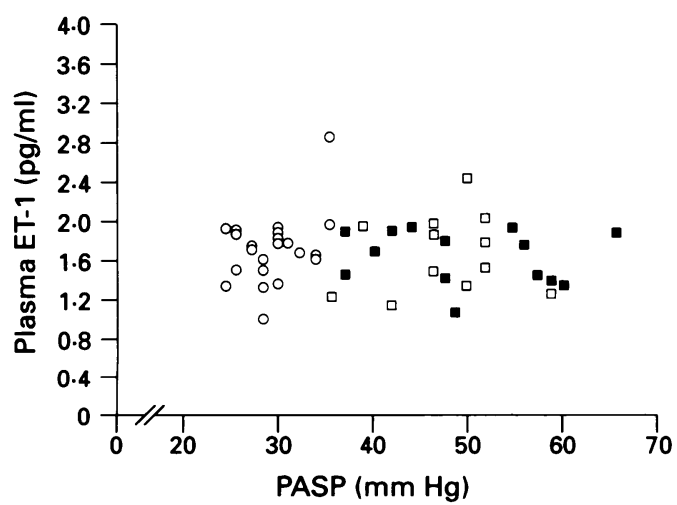

Figure 3 Relationship between plasma ET-1 concentrations and pulmonary artery systolic pressure (PASP) in 48 patients affected by systemic sclerosis. = Pulmonary hypertension alone $(n=14)$; $\square=$ pulmonary hypertension in combination with systemic arterial hypertension $(n=12) ; O=$ remaining patients $(n=22) . \mathrm{r}=0.016 ; p=0.912$
Two other important factors seem to deserve particular attention. First, an arteriovenous ET-1 concentration difference has been reported in patients with pulmonary hypertension, ${ }^{15}$ therefore assay of ET-1 in blood taken from an antecubital vein might not reflect the effective concentration of ET-1 in the pulmonary circulation. Second, endothelial cells in culture release more than $80 \%$ of newly generated ET-1 into the abluminal side, while only $20 \%$ is secreted into the luminal one, ${ }^{25}$ thus supporting the hypothesis that circulating ET-1 might not reflect the local concentration of ET-1 in the pulmonary vessel wall. Therefore, although our findings require confirmation by measurement of ET-1 in blood from the small pulmonary arteries and veins and from the right atria, they may indicate a more complex interaction between ET-1 and the pulmonary vasculature, prompting a general reassessment of the role of ET-1 in pulmonary hypertension.

In agreement with this suggestion, Deleuze et $a l^{26}$ have reported that infusion of ET-1 caused significant dilatation of the pulmonary vasculature in calves. Indeed, pulmonary endothelial cells express more ET $\mathrm{B}_{\mathrm{B}}$ receptors, ${ }^{27}$ which are known to mediate vasorelaxation through nitric oxide and prostacyclin synthesis, ${ }^{28}$ than ETA receptors that lead to vasoconstriction through an increase in cytosolic free calcium ion ${ }^{29}$ and are expressed by the vascular smooth muscle cells. As endothelial cells are not permeable to external ET $-1,{ }^{23}$ the circulating peptide therefore cannot bind $E T_{A}$ receptors.

Each mature isoform of ET-1 (ET-1, ET-2, ET-3) derives from a distinct gene and is cleaved from the corresponding precursor peptide (big-ET) by a membrane bound endothelin converting enzyme, and can also be secreted into the bloodstream. ${ }^{30}$ Most endothelin radioimmunoassays do not adequately distinguish among the mature isoforms of endothelin and are also cross reactive with big-ETs. ${ }^{31}$ Therefore, some previous studies ${ }^{14-16}$ could have overestimated circulating ET-1 levels by evaluating big-ET-1 in addition to ET-1. In agreement with this hypothesis, increased levels of plasma big-ET-1 have been described in patients with pulmonary hypertension, ${ }^{32}$ and were significantly greater than those of ET-1.32 In the current study, we separated ET-1 from the other ET isoforms and precursors by high performance liquid chromatography. With this method, the levels of circulating ET-1 from both control subjects and patients with SSc were two to 10-fold lower than those previously described in patients with pulmonary hypertension. ${ }^{14-16}$ It could therefore be speculated also that the lack of correlation between plasma ET-1 and pulmonary pressures may simply reflect the use of a more appropriate method for ET-1 assay.

In this context, it is interesting that systemic hypertension also was not associated with particular changes in plasma ET-1 levels in patients with SSc. However, we do not find this surprising, as a causal relationship between increased ET-1 concentrations in plasma and 
high blood pressure has been demonstrated only in two patients affected by an extremely rare form of ET-1 secreting malignant haemangioendothelioma. ${ }^{33}$ In addition, some early reports describing an increase in plasma ET-1 levels in patients affected by essential hypertension ${ }^{18-20}$ were not confirmed by other studies showing that patients with essential hypertension who had a normal renal function also had normal plasma ET-1 levels. ${ }^{34-37}$ A.s our patients had normal serum creatinine concentrations and glomerular filtration rates, as evaluated by the renal scintigraphy, it seems reasonable to propose that the absence of kidney damage may explain the presence of similar ET-1 levels in both hypertensive and normotensive patients with SSc.

From these observations, it would appear that SSc per se influences ET-1 secretion into the bloodstream, which makes the role of increased ET-1 levels uncertain. Nevertheless, in cultured human fibroblasts ET-1 induced a dose dependent increase of ${ }^{3} \mathrm{H}$-thymidine incorporation in addition to de novo protein and collagen synthesis. ${ }^{7}$ Thus ET-1 might exert a profibrotic action in vivo in patients with SSc, favouring the progressive perivascular sclerosis of the skin and visceral organs.

1 LeRoy E C. Systemic sclerosis (scleroderma). In Wyngaarden J B, Smith L H Jr, eds. Cecil textbook of medicine. Philadelphia: Saunders, 1988; 2018-33.

2 Greenwald G I, Tashkin D P, Gong H Jr, et al. Longitudina changes in lung function and respiratory symptoms in progressive systemic sclerosis. $A m \mathcal{F}$ Med 1987; 83: 83-92.

3 Weaver A L, Divertie M B, Titus J L. Pulmonary scleroderma. Dis Chest 1968; 54: 490-8.

4 Lee P, Langevitz P, Buskila D. Mortality in systemic sclerosis (scleroderma). Arthritis Rheum 1990; 33: S156.

5 Gilliland B C. Progressive systemic sclerosis (diffuse scleroderma). In: Braunwald E, Isselbaker $\mathrm{K} J$ Petersdorf R G, Wilson J D, Martin J B, Fauci A S, eds. Harrison's principles of internal medicine. New York: McGraw-Hill Inc, 1987; 1828-32.

6 Yamane K, Miyauchi T, Yuhara T, Akama T, Kashiwagi $H$. Significance of plasma endothelin-1 levels in patients with Significance of plasma endothelin-1 levels in patien

7 Kahaleh M B. Endothelin, an endothelial-dependent vasoconstrictor in scleroderma. Arthritis Rheum 1991; 34 978-83.

8 Subcommittee for scleroderma criteria of the American Rheumatism Association Diagnostic and Therapeutic Criteria Committee. Preliminary criteria for the classification of systemic sclerosis (scleroderma). Arthritis Rheum 1980; 23: 581-90.

9 Wagner O F, Nowotny P, Vierhapper H. Plasma concentrations of endothelin in man: artero-venous differences and release during venous stasis. Eur $\mathcal{f}$ Clin Invest 1990; 20: $502-5$.

10 Hatle L, Brubakk A, Tromsdal A, Angelsen B. Non invasive assessment of pressure drop in mitral stenosis by Dopple ultrasound. Br Heart f 1978; 40: 131-40.

11 Currie P J, Seward J B, Chan K L, et al. Continuous-wave Doppler determination of right ventricular pressure: simultaneous Doppler-catheterization study in 127 patients. $\mathcal{F}$ Am Coll Cardiol 1985; 6: 6750-6.
12 LeRoy E C, Black C, Fleischmajer R, et al. Scleroderma systemic sclerosis): classification, subsets and pathogenesis. F Rheumatol 1988; 15: 202-5.

13 Yamane K, Kashiwagi $\mathrm{H}$, Suzuki N, et al. Elevated plasma levels of endothelin-1 in systemic sclerosis. Arthritis Rheum 1991; 34: 243-4

14 Cody R J, Haas G J, Binkley P F, Capers Q, Kelley R. Plasma endothelin correlates with the extent of pulmonary hypertension in patients with chronic pulmonary hypertension in patients with chron

15 Stewart D J, Levy R D, Cernacek P, Langleben D. Increased plasma endothelin-1 in pulmonary hypertension: marke or mediator of disease? Ann Int Med 1991; 114: 454-9.

16 McMurray J J, Ray S G, Abdullah I, Dargie H J, Morton J J. Plasma endothelin in chronic heart failure. Circulation 1992; 85: 1374-9.

17 Margulies K B, Hildebrand F L, Lerman A, Perella M A Burnett J C. Increased endothelin in experimental heart failure. Circulation 1990; 82: 2226-30.

18 Saito $\mathrm{Y}$, Nakao K, Mukoyama M, Imura H. Increased plasma endothelin level in patient with essential hyperplasma endothelin level in patient with esse
tension [letter]. N Eng 7 Med 1990; 322: 205.

19 Shichiri M, Hirata Y, Ando K, et al. Plasma endothelinlevels in hypertension and chronic renal failure. Hypertension 1990; 15: 493-6.

20 Kohno M, Yasunari K, Murakawa K L, et al. Plasma immunoreactive endothelin in essential hypertension. $A m$ 7 Med 1990; 88: 614-8.

21 Summer D. Lies, damned lies-or statistics? I Hyperten 1992; 10: 3-8.

22 Vancheeswaran R, Magoulas T, Efrat G, et al. Circulating endothelin-1 levels in systemic sclerosis subsets. A marker of fibrosis or vascular dysfunction? $\mathcal{F}$ Rheumatol 1994; 21 . 1838-44.

23 Ungerer R G, Taskin D P, Furst D. Prevalence and clinical correlates of pulmonary arterial hypertension in pro-
gressive systemic sclerosis. $A m \nexists M e d$ 1983; 75: 65-74.

24 Morelli S, De Marzio P, Valesini G, Bonavita M S Ipertensione polmonare e sclerosi sistemica. G Ital Cardio 1993; 23: 871-5.

25 Yoshimoto S, Ishizaki Y, Mori A, et al. The role of cerebra microvessel endothelium in regulation of cerebral blood flow through production of endothelin-1. 7 Vasc Med Biol 1990; 2: 178 .

26 Deleuze $\mathrm{P}$ H, Adnot S, Shiiya N, et al. Endothelin dilates bovine pulmonary circulation and reverses hypoxic pulmonary vasoconstriction. $f$ Cardiovasc Pharmacol 1992; 19: 354-60.

27 Lüscher T F. Endothelin, endothelin receptors, and antagonists. Curr Opin Nephrol Hypertens 1994; 3: 92-8.

28 De Nucci G, Thomas R, D'Orleans-Juste P, et al. Pressor effects of endothelin are limited by its removal in the pulmonary circulation and by release of prostacyclin and endothelium derived relaxing factor. Proc Natl Acad Sci USA 1988; 85: 9797-800.

29 Rubanyi G M, Parker Botelho L H. Endothelins. FASEB $\mathcal{Y}$ 1991; 5: 2713-20.

30 Yanagisawa $M$, Kurihara $H$, Kimura $S$, Tamake $Y$, Kobayashi M, Mitsui Y. A novel potent vasoconstrictor peptide produced by vascular endothelial cells. Nature 1988; 332: 411-5.

31 Schuller M, Stetter R, Skrabal S, Missbichler A Woloszezuk W, Hartter E. Radioimmunoassay of immunoreactive C-terminal big-endothelin(22-38). Eur $\mathcal{f}$ Clin Chem Clin Biochem 1991;29: 147-50.

32 Pacher R, Berger-Klein J, Globits S, et al. Plasma bigendothelin-1 concentrations in congestive heart failure patients with or without systemic hypertension. $A m f$ Cardiol 1993; 71: 1293-9.

33 Yokokawa K, Takahara M, Kohno K, et al. Hypertension associated with endothelin-secreting malignant hemangioendothelioma. Am Intern Med 1991; 114: $213-5$.

34 Schiffrin E L, Thibault G. Plasma endothelin in human essential hypertension. Am ₹ Hypertens 1991; 4: 303-8.

35 Davenport A P, Ashby M J, Easton P, et al. A sensitive radioimmunoassay measuring endothelin-like immunoreactivity in human plasma. Comparison of levels in patients with essential hypertension and normotensive control subjects. Clin Sci 1990; 78: 261-4.

36 Lüscher T F, Seo B, Bühler F R. Potential role of endothelin in hypertension. Controversy on endothelin in hypertension. Hypertension 1993; 21: 752-7.

37 Nassar G, Badr K R. Endothelin in kidney disease. Cur Opin Nephrol Hypertens 1994; 3: 86-91. 